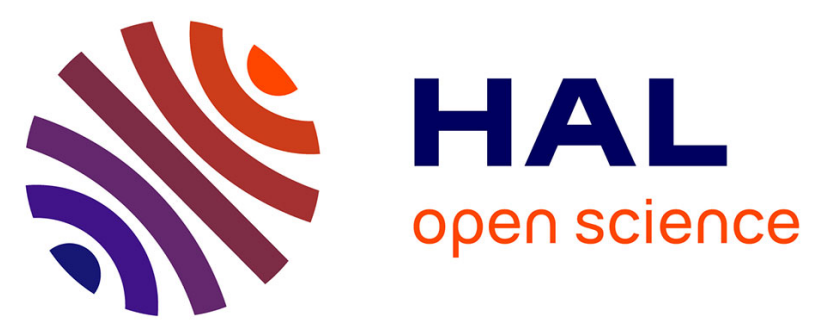

\title{
Determining the influence of telomere dysfunction and DNA damage on stem and progenitor cell aging - what markers can we use?
}

Kodandaramireddy Nalapareddy, Hong Jiang, Luis Miguel Guachalla

Gutierrez, K. Lenhard Rudolph

\section{To cite this version:}

Kodandaramireddy Nalapareddy, Hong Jiang, Luis Miguel Guachalla Gutierrez, K. Lenhard Rudolph. Determining the influence of telomere dysfunction and DNA damage on stem and progenitor cell aging - what markers can we use?. Experimental Gerontology, 2008, 43 (11), pp.998. 10.1016/j.exger.2008.09.002 . hal-00499065

\section{HAL Id: hal-00499065 https://hal.science/hal-00499065}

Submitted on 9 Jul 2010

HAL is a multi-disciplinary open access archive for the deposit and dissemination of scientific research documents, whether they are published or not. The documents may come from teaching and research institutions in France or abroad, or from public or private research centers.
L'archive ouverte pluridisciplinaire HAL, est destinée au dépôt et à la diffusion de documents scientifiques de niveau recherche, publiés ou non, émanant des établissements d'enseignement et de recherche français ou étrangers, des laboratoires publics ou privés. 


\section{Accepted Manuscript}

Determining the influence of telomere dysfunction and DNA damage on stem and progenitor cell aging - what markers can we use?

Kodandaramireddy Nalapareddy, Hong Jiang, Luis Miguel Guachalla

Gutierrez, K. Lenhard Rudolph

PII:

S0531-5565(08)00294-5

DOI:

10.1016/j.exger.2008.09.002

Reference:

EXG 8544

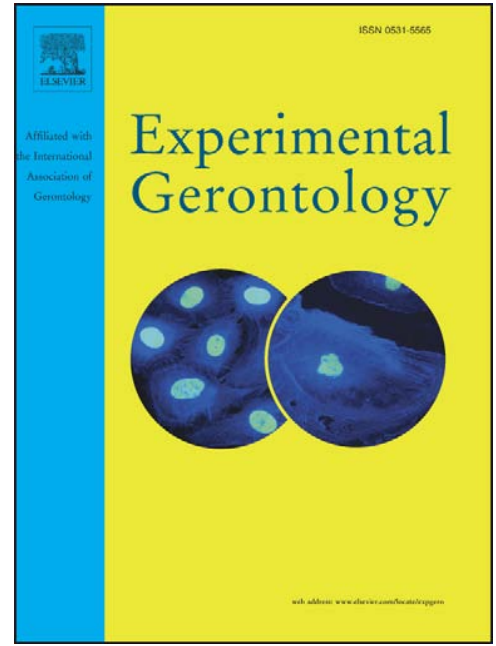

To appear in:

Experimental Gerontology

Received Date:

18 July 2008

Revised Date:

4 September 2008

Accepted Date:

4 September 2008

Please cite this article as: Nalapareddy, K., Jiang, H., Guachalla Gutierrez, L.M., Rudolph, K.L., Determining the influence of telomere dysfunction and DNA damage on stem and progenitor cell aging - what markers can we use?, Experimental Gerontology (2008), doi: 10.1016/j.exger.2008.09.002

This is a PDF file of an unedited manuscript that has been accepted for publication. As a service to our customers we are providing this early version of the manuscript. The manuscript will undergo copyediting, typesetting, and review of the resulting proof before it is published in its final form. Please note that during the production process errors may be discovered which could affect the content, and all legal disclaimers that apply to the journal pertain. 
Determining the influence of telomere dysfunction and DNA damage on stem and progenitor cell aging - what markers can we use?

Kodandaramireddy Nalapareddy ${ }^{1}$, Hong Jiang ${ }^{1,2}$,Luis Miguel Guachalla Gutierrez ${ }^{1}$ and K. Lenhard Rudolph $^{1 *}$

1. Institute of Molecular Medicine and Max-Planck-Research Group on Stem Cell Aging, University of Ulm, 89081, Germany.

2. Kidney Disease Center, The First Affiliated Hospital, College of Medicine, Zhejiang University

* Corresponding author:

K. Lenhard Rudolph

Department of Molecular Medicine

Max-Planck-Research-Group on Stem Cell Aging

University of Ulm

Albert-Einstein-Allee 11

89081 Ulm, Germany

Lenhard.Rudolph@uni-ulm.de

Tel./Fax: 0049-731-5036-100 / -102 
The decline in organ maintenance and function is one of the major problems limiting quality of life during aging. The accumulation of telomere dysfunction and DNA damage appears to be one of the underlying causes. Uncapping of chromosome ends in response to critical telomere shortening limits the proliferative capacity of human cells by activation of DNA damage checkpoints inducing senescence or apoptosis. Telomere shortening occurs in the vast majority of human tissues during aging and in chronic diseases that increase the rate of cell turnover. There is emerging evidence that telomere shortening can limit the maintenance and function of adult stem cells - a cell type of utmost importance for organ maintenance and regeneration. In mouse models, telomere dysfunction leads to a depletion of adult stem cell compartments suggesting that stem cells are very sensitive to DNA damage. Both the rarity of stem and progenitor cells in adult organs and their removal in response to damage make it difficult to assess the impact of telomere dysfunction and DNA damage on stem and progenitor cell aging. Such approaches require the development of sensitive biomarkers recognizing low levels of telomere dysfunction and DNA damage in stem and progenitor cells. Here, we review experimental data on the prevalence of telomere dysfunction and DNA damage during aging and its possible impact on stem and progenitor cell aging. 


\section{ACCEPTED MANUSCRIPT}

\section{Telomere dysfunction}

Telomeres are repetitive DNA sequences that cap the ends of eukaryotic chromosomes (Blackburn, 1997). Telomere capping is required to prevent an activation of DNA damage signaling at the chromosome termini. It has been proposed that individuals are born with long telomeres (10-15 kbs in humans), and that aging is in part the result of a decrease in telomere length. In cell culture, telomeres shorten during each cell division (Harley et al., 1990) due to the "end-replication-problem" of DNA polymerase and due to processing of telomeres during the cell cycle. In response to critical shortening, telomeres lose their capping function at the chromosome ends.

Uncapped, dysfunctional telomeres trigger DNA damage responses that lead to an activation of the p53 pathway(Chin et al., 1999). Two checkpoints limit the lifespan of primary human fibroblast in response to telomere dysfunction: The first checkpoint (first mortality stage $=$ M1) induces a permanent cell cycle arrest named 'senescence'(Wright and Shay, 1992). Cells with impaired p53 checkpoint function can bypass senescence and continue to proliferate despite the presence of dysfunctional telomeres. However, continuous telomere shortening leads to further accumulation of telomere dysfunction inducing a second checkpoint (second mortality stage = M2) named 'crisis'. Crisis is a p53independent event and is characterized by massive chromosomal instability and cell death(Wright and Shay, 1992). Both senescence and crisis limit the replicative lifespan of human cells, thus, acting as tumor suppressor mechanisms that limit the lifespan of transformed cells(Wright and Shay, 1992). As a downside, these checkpoints could also contribute to the exhaustion of cellular functions impairing organ maintenance during ageing.

Most human tissues and organs show significant telomere shortening during ageing including peripheral blood cells, lymphocytes, kidney epithelium, vascular endothelial cells, hepatocytes, intestinal epithelial cells, lung epithelial cells, muscle, and others (Jiang et al., 2007). However, there is still a continuous debate whether this level of telomere shortening leads to telomere dysfunction impairing organ maintenance and regeneration during human aging. In the following section we briefly review 


\section{ACCEPTED MANUSCRIPI}

experimental studies investigating the prevalence of telomere dysfunction, DNA damage, and checkpoint induction (senescence and apoptosis) during organismal aging.

\section{Telomere dysfunction and DNA damage during aging}

It has been postulated that accumulation of DNA damage can contribute to human aging(Lieber and Karanjawala, 2004). Several mechanisms can induce DNA damage in cells including replication errors, telomere shortening and generation of reactive oxygen species (ROS), toxic metabolites, background irradiation, ultraviolet radiations and exposure to environmental toxins among others(Vijg, 2008). Different types of DNA lesions occur in response to these different types of damage including the oxidation of nucleotides, single- and double-strand breaks, depurinations, depyrmidations, interstrand crosslinks, and telomere dysfunction. Despite the prevalence of telomere shortening in almost all human tissues during aging(Jiang et al., 2007), the relative contribution of telomere dysfunction to organismal aging remains under debate. Telomere dysfunction represents a deleterious type of DNA damage due to the limited capacity of cells in repairing telomeric lesions. It has been suggested that micro-homology based mechanisms lead to the induction of chromosomal fusion in response to telomere dysfunction(Maser et al., 2007). However, chromosomal fusions are not stable and are prone to breakage when cells enter the cell cycle. It has also been shown that single dysfunctional telomeres induce repeated fusion/breakage cycles that lead to chromosomal instability(Sabatier et al., 2005) and may account for increased cancer formation during aging.

DNA damage responses elicited by dysfunctional telomeres appear to be similar to those induced by DNA double strand breaks. The earliest response is the formation of DNA damage foci containing different proteins such as 53bp1, Mdc1, Mre11, Rad50, Nbs1, among others (d'Adda di Fagangna et al. 2003). These proteins have a functional role in detecting and processing damaged DNA and furthermore activate downstream signaling pathways. In addition, DNA damage foci contain $\gamma \mathrm{H} 2 \mathrm{AX}$, a 
phosphorylated form of the histone H2AX.

As discussed above, it is difficult to discriminate the DNA damage responses elicited by dysfunctional telomeres from that of DNA breaks within the genome. In contrast to the DNA damage foci formed at dysfunctional telomere(d'Adda di Fagangna et al., 2003), extra-telomeric DNA damage involves the formation of DNA damage foci throughout the genome(Sedelnikova et al., 2004). To distinguish telomere dysfunction induced DNA damage foci (TIFs) from DNA breaks within the genome investigators have used co- staining for (i) telomere components (telomere fluorescence in situ hybridization, immunofluorescence against telomere binding proteins: $\operatorname{Trf} 1, \operatorname{Trf} 2)$ and (ii) DNA damage foci components. The drawback of this assay is that TIFs normally form at telomere-free chromosome ends containing no or very low amounts of telomeric DNA and telomere binding proteins. Therefore, costaining techniques likely underestimate the contribution of TIFs to the total amount of DNA damage foci in cells or tissues.

Studies on organismal aging have revealed some evidence for an accumulation of DNA damage during ageing (Table 1). In aging mice an increase in the percentage of organ cells containing DNA damage $(\gamma \mathrm{H} 2 \mathrm{AX})$ foci has been seen in various organs like liver (9\% of the cells), testis (11\% of the cells), kidney (12\% of the cells), lung (15\% of the cells), and brain ( $7.4 \%$ of the cells, Sedelnikova et al., 2004). In this study only a minor proportion (10-15\%) of DNA damage foci was found to co-localize with telomeric markers (TIFs). However, as discussed above, it is possible that this method underestimates the true co-localization to telomeres. Studies on aging baboons have specifically addressed this question by quantification of $\gamma \mathrm{H} 2 \mathrm{AX}$ foci at telomeres(Herbig et al., 2006, Jeyapalan et al., 2007).These studies revealed an increase in $\gamma \mathrm{H} 2 \mathrm{AX}$ foci at telomeres in aging skin, but not in other organs such as muscle. 


\section{ACCEPTED MANUSCRIPT}

In humans, an increase in DNA damage foci has been observed in lymphocytes during aging (Sedelnikova et al., 2008) and in intestinal epithelial cells of patients with colitis ulcerosa (Risques et al., 2008) - a chronic inflammatory disease associated with accelerated telomere shortening. In addition, an increase in DNA double strand and single stand breaks was detected in aging sperm (Schmid et al., 2007, Singh et al., 2003) in brain of patients with Alzheimer disease(Mullaart et al., 1990), and in peripheral blood lymphocytes (Chicca et al. 1996). Moreover, an increase in DNA damage signals has been observed in some tissues of aging humans including kidney (Melk et al., 2004), skeletal muscle (Welle et al., 2004), bone marrow stroma (Zhou et al., 2008), and brain of patients with Alzheimer's disease (Cenini et al., 2008). It remains an open question to what extend dysfunctional teloemres contribute to the total amount of DNA damage accumulating during human aging.

Another open question is to what extent telomere dysfunction and DNA damage occurs in aging stem cells. Experimental studies on neurodegenerative disorders have suggested that non-proliferative cells may be particularly prone to the accumulation of DNA damage(for review see Rass et al., 2007). However, there is accumulating evidence for a decline in stem cell function during aging(Rando, 2007). Studies on DNA repair deficient mice and telomerase knockout mice have shown that DNA damage(Nijnik et al., 2007) and telomere dysfunction(Rossi et al., 2008, Choudhury et al., 2007) limit the function of adult stem cells. The impaired function of hematopoietic stem cells (HSCs) in response to telomere dysfunction involves both the activation of stem cell intrinsic checkpoints and alterations of the stem cell environment(Ju et al., 2007b). The relative contribution of these mechanisms to human aging remains to be determined(Song, 2008). Studies on aging telomerase deficient mice have also revealed a decrease in HSC maintenance compared to wild type mice (Choudhury et al., 2007). In contrast to the decline in hematopoietic progenitor cells during human aging, the number of HSCs increases during aging in some laboratory inbred mouse strains including the C57B1/6J strain. In aging telomere dysfunctional mice and in mouse mutants with impaired DNA damage repair this agedependent increase in HSC number is reduced compared to wild type mice (Rossi et al. 2007). Also in 
absolute number there was a reduction in HSC numbers in bone marrow of aged telomere dysfunctional mice compared to wild type mice (Choudhury et al. 2007). Together, these results indicate that DNA damage and telomere dysfunction can impair the self renewal of HSCs. Similar findings appear to hold true for intestinal stem cells since there is a strong reduction in basal crypts in aging telomere dysfunctional mice compared to wild type mice (Choudhury et al. 2007, Schaetzlein et al. 2007). In contrast, there are reports on increased number of label retaining cells in hair bulge of telomere dysfunctional mice compared to wild type mice (Flores et al. 2005). It needs yet to be confirmed with more specific markers whether there is a true increase in stem cell number in the hair bulge of telomere dysfunctional mice. Such results would indicate that telomere dysfunction can have different effects on stem cell maintenance depending on the organ compartment.

Studies on telomere dysfunctional and DNA repair deficient mice have shown that progenitor cells appear to be more sensitive to DNA damage than stem cells. The reduction in hematopoietic progenitor cells in telomere dysfunctional mice was more pronounced than the reduction in HSC number (Ju et al. 2007, Choudhury et al. 2007, Schaetzlein et al. 2007, Rossi et al. 2007). One possible explanation for these findings is that quiescent stem cells may be better protected against DNA damage compared to transient amplifying cells. An alternative explanation is that DNA damage responses are reduced in stem cells compared to progenitor cells. Along these lines, there is evidence for impaired DNA damage checkpoint function in embryonic stem cells compared to somatic cells (Hong and Stambrook 2004). Moreover, DNA damage signal induction in response to telomere dysfunction is mitogen dependent (Satyanarayana et al. 2004) and DNA damage responses may thus be reduced in quiescent stem cells compared to highly proliferative progenitor cell compartments.

Together, these studies indicate that telomere dysfunction and DNA damage can impair the function and maintenance of stem and progenitor cells. The higher resistance to DNA damage seen in stem cells compared to progenitor cells may lead to an accumulation of DNA damage in aging stem 


\section{ACCEPTED MANUSCRIPT}

cells, and may thus represent a possible mechanism through which stem cell aging can lead to cancer (Rossi et al. 2007b).

As dysfunctional telomeres and DNA damage can either induce senescence or apoptosis, analysis of the prevalence of apoptosis and senescence could help to identify organs in which telomere dysfunction and DNA damage contribute to the aging process. In the following section we briefly summarize studies on the prevalence of apoptosis and senescence in aging organisms.

\section{Senescence and aging}

Studies on human fibroblasts have shown that a sentinel of dysfunctional telomeres induce senescence in response to telomere shortening(Harley et al., 1990; Wright and Shay, 1992). It was estimated that 4 to 5 dysfunctional telomeres per cell are required to activate cell cycle checkpoints inducing senescence(Zou et al., 2004). The formation of DNA damage foci (see above) represents the initial response to telomere dysfunction(d'Adda et al., 2003; Satyanarayana et al., 2004). DNA damage foci activate ATM/Chk2 and ATR/Chk1 kinases inducing p53 and its downstream target p21(Brown et al., 1997). Functional studies on human fibroblast senescence have shown that abrogation of ATM, ATR, Chk2, p53, or p21 is sufficient to abrogate or delay the induction of senescence(Brown et al., 1997; d'Adda et al., 2003; Gire et al., 2004). It has been proposed that induction of p53 and p21 represents an early response inducing senescence, whereas the up-regulation of p16 appears to be a late event after the induction of replicative senescence(Stein et al., 1999). Moreover, it has been shown that senescent cells exhibit heterochromatin foci formation associated with an impairment of the canonical Wnt signaling pathway in senescent cells(Ye et al., 2007). Besides these molecular markers, an increased activity of lysosomal $\beta$-Galactosidase (at pH6) occurs in senescent cells (senescence associated $\beta$-Galactosidase $=$ SA- $\beta-$ Gal) (Lee et al. 2006). However, this marker has to be analysed with caution since it lacks 


\section{ACCEPTED MANUSCRIPT}

specificity and shows background activity at a lower PH.

Experimental data indicate that senescence can be induced by various telomere-independent mechanisms including (i) over-activation of oncogenes(Serrano et al., 1997), (ii) over-stimulation with mitogens(Sherr and DePinho, 2000), (ii) oxidative stress(Parrinello et al., 2003), (iv) irradiation(Suzuki and Boothman, 2008), and (v) chemotherapy(Haug et al., 2008). The only specific marker of telomere induced senescence is the formation TIFs, however, this marker has a lack of sensitivity (see above). In conclusion, the current senescence markers are difficult to use for in vivo studies and most of these markers can not discriminate between replicative senescence and other forms of senescence. In addition, non-senescent cells can express senescence markers. For example, $\gamma \mathrm{H} 2 \mathrm{AX}$ foci are present in intestinal stem and progenitor cells of telomere dysfunctional mice(Schaetzlein et al., 2007b; Choudhury et al., 2007b). However, only a small subset of these cells are cell cycle arrested(Choudhury et al., 2007; Schaetzlein et al., 2007). Together, reports on the prevalence of senescent cells in vivo have to be interpreted with caution.

Many experimental studies have attempted to analyse the prevalence of senescent cells in aging tissues of human and model organisms. These studies revealed some evidence for senescent cells in aging tissues (Table 2). In humans, an increase in SA- $\beta-$ Gal positive cells was described in skin keratinocytes (Dimri et al., 1995), cornea epithelium (Mimura and Joyce, 2006), ischemic heart (Minamino et al., 2002), arterosclerotic plaques (Gorenne et al., 2006), articular chondrocytes (Martin and Buckwalter 2001), and in liver cirrhosis - the end stage of chronic liver disease(Wiemann et al., 2002). In addition, an upregulation of DNA damage pathways associated with senescence has been obersved in various tissue of aging humans including activation of p53, p21 and p16 (see above and Table 1). An increase in SA- $\beta-$ Gal activity and senescence associated DNA damage signaling has also been observed in aging animals (Table 1,2). However, it remains to be analysed whether this increase in SA- $\beta-$ Gal activity DNA damage signaling is truly associated with senescence cell cycle arrest in vivo. There is evidence that upregulation of p16 can limit the regenerative capacity of stem cells in aging 


\section{ACCEPTED MANUSCRIPI}

mice(Janzen et al., 2006; Krishnamurthy et al., 2006; Molofsky et al., 2006). The mechanisms that lead to an activation of p16 in aging mice remain to be elucidated. Given the long telomeres in inbred mouse strains this upregulation of p16 is likely independent of telomere dysfunction.

The most thorough analysis for the detection of replicative senescent cells in vivo was the screening for the prevalence of TIFs $(\gamma \mathrm{H} 2 \mathrm{AX}$-positive DNA damage foci at telomeres) in aging baboons(Herbig et al., 2006, Jeyapalan et al., 2007). This study revealed an accumulation of TIFs in skin but not in muscle of aging baboons. It was not analyzed whether the marker-positive cells in the skin were truly senescent in the sense that the cells were cell cycle arrested (non-dividing).

Studies on telomerase knockout mice provided evidence that telomere dysfunction does not lead to strong accumulation of senescent-marker positive cells in different organs(Choudhury et al., 2007). Instead, the mice showed a depletion of intestinal and hematopoietic stem and progenitor cells (Choudhury et al., 2007, Rossi et al. 2007). A possible explanation is that - unlike the observation from in vitro cell cultures - senescent cells do not persist in vivo. Along these lines, it has been suggested that senescent cells can be removed by immune responses(Xue et al., 2007) or apoptosis(Choudhury et al., 2007).

All together, it appears that the currently available markers of senescence lack specificity and likely underestimate the influence of telomere dysfunction on organismal aging.

\section{Apoptosis and aging}

Apoptosis is the cellular response to an accumulation of macromolecular damage. Cell intrinsic and extrinsic pathways can trigger apoptosis, which common endpoint is the activation of effector proteases called caspases. Apoptotic cells can be detected by their characteristic apoptotic nuclear morphology including fragmentation of genomic DNA by endonucleases. Similar to the senescence checkpoint, 


\section{ACCEPTED MANUSCRIPT}

apoptosis is regarded as a tumor suppressor mechanism preventing the accumulation and spread of damaged cells. In contrast, increasing rates of apoptosis could contribute to impaired organ maintenance during aging. Some of the studies on the prevalence of apoptosis in aging tissues are summarized in Table 3.

Studies on telomerase knockout mice have confirmed that telomere dysfunction increases apoptosis in lymphocytic progenitor cells, intestinal progenitor cells and germ cells(Choudhury et al., 2007; Ju et al., 2007b; Lee et al., 1994). An age dependent increase in apoptosis rates has also been observed in wild type mice and rats. Liver, muscle, testis and heart from old wild type mice displayed increased rates of cleaved caspase-3 as compared to young controls(Kujoth et al., 2005). In addition, the gastric epithelium of aging rats displayed an increased expression of caspase-3 and -9 (Tarnawski et al., 2007).

In humans, an increased expression of pro-apoptotic signaling molecules and caspases was found in patients with Alzheimer's disease (Albrecht et al., 2007) and in various tissues including peripheral blood lymphocytes (Aggarawal and Gupta, 1998), brain (Gua et al., 2004), lung (Healy et al., 1998), and pancreas (Maedler et al., 2006). Increased rates of apoptosis have also been found in sarcopenia and there is ongoing discussion that increased rates of apoptosis may cause the progression of muscle loss during human aging(Marzetti and Leeuwenburgh, 2006). However, apoptosis rates do not increase in the wall of coronary arteries during human aging(Boddaert et al., 2005) and are decreased in aging sperm (Singh et al., 2003). In addition, it was reported that lymphocytes from aged individuals were resistant to pro-apoptotic effects of inflammatory cytokines(Larbi et al., 2007).

Together, the data on modulation of apoptosis during aging are not uniform and require further analysis. In addition, the mechanisms that increase apoptosis during aging remain to be defined.

\section{Biomarkers of telomere dysfunction and DNA damage}




\section{ACCEPTED MANUSCRIPT}

The above studies illustrate that telomere dysfunction and DNA damage likely contribute to the pathophysiology of human aging. However, it is difficult to determine the true impact of DNA damage and telomere dysfunction to aging because of following limitations:

(i) Traditional markers of telomere dysfunction and DNA damage are not easy to detect in vivo and are not applicable for clinical routine diagnostics.

(ii) There is evidence that cells with higher levels of telomere dysfunction or DNA damage are cleared in vivo. Especially, stem cells are very sensitive to DNA and telomere damage and are depleted in response to such lesion. Thus, analyzing the prevalence of DNA damage and telomere dysfunction likely underestimates the true impact of these lesion on aging.

(iii) It is difficult to quantify the activation of checkpoints induced by telomere dysfunction and DNA damage (apoptosis and senescence). In addition, these checkpoints can be induced by a variety of different stimuli making it difficult to determine the underlying cause of checkpoint activation.

Sensitive biomarkers that indicate low rates of DNA and/or telomere damage could help to determine the influence of DNA damage on aging and disease. To identify marker proteins of telomere dysfunction in pre-senescent cells we have recently used a knockout mouse lacking the RNA component of telomerase (Terc-/-). Late generation (G3-G4) Terc-/- mice show evidence of telomere dysfunction and premature aging of high-turnover organs but lack an accumulation of senescent cells (Choudhury et al., 2007). An unbiased proteomic approach (CE-TOF-MS analysis) has identified 4 marker proteins that were up-regulated in aging G3-G4 Terc-/- mice with dysfunctional telomeres but not in wildtype mice with long telomeres: CRAMP, stathmin, EF-1 $\alpha$, chitinase (Jiang H.et al, 2008). The study showed that the same marker proteins were up-regulated in culture medium of human fibroblast in response to telomere-induced senescence and $\gamma$-irradiation. Of note, an analysis of these marker proteins in human blood and tissue samples revealed an increased expression of these marker proteins in human aging, age associated disease, and in chronic diseases that have previously been associated with telomere dysfunction, e.g., cirrhosis, myelodysplastic syndromes. Together, this study provides further support for 
the concept that telomere dysfunction and DNA damage contribute to human aging. The identified biomarkers are easily detectable in blood samples and thus provide a powerful tool to better analyze the influence of telomere dysfunction and DNA damage on disease processes associated with human aging. Moreover, these biomarkers could be useful to develop prevention strategies slowing the accumulation of DNA damage and the evolution of age associated disease. It is also conceivable that secreted proteins from damaged cells directly influence the aging process. Along these lines it has been shown that systemic acting factors impair the function of adult stem cells during aging(Conboy et al., 2005). Therefore, a better understanding of the molecular markers induced by telomere dysfunction and DNA damage may not only provide novel diagnostic tools but could point to targets for future therapies aiming to improve organismal fitness during aging.

\section{Conclusions}

There is accumulating evidence that telomere dysfunction and DNA damage contribute to the pathophysiology of human aging. The development of novel biomarkers will help to better characterize this interconnection. The currently available biomarkers cannot distinguish telomere dysfunction and intra-chromosomal DNA damage and thus cannot determine the relative contribution of each of these lesions to human aging. A discrimination between these lesion is further complicated because telomere dysfunction increases the amount of intra-chromosomal DNA damage by induction of fusion-bridgebreakage cycles (Sabatier et al. 2005).

The contribution of DNA damage to aging may continuously be underestimated because

damaged cells, specifically stem and progenitor cells, are depleted in response to DNA damage. The loss of adult stem and progenitor cells could have major contributions to the impairment of organ maintenance and regeneration during aging and chronic disease. The identification of specific markers of adult stem cells(Barker et al., 2007) will help to analyze stem cell reserve in aging organs and tissues. Responses to DNA damage in adult stem cells may differ from those in somatic cells. A careful 
characterization of such differences could lead to the identification of biomarkers specifically indicating DNA damage in stem cell compartments. Together, the identification of both stem cell markers and biomarkers for damage accumulation should help to develop prevention strategies and therapies aiming to improve stem and progenitor cell function, tissues maintenance, and healthy aging. 


\section{Reference List}

Aggarwal,S. and Gupta,S. 1998. Increased apoptosis of T cell subsets in aging humans: altered expression of Fas (CD95), Fas ligand, Bcl-2, and Bax. J. Immunol. 160, 1627-1637.

Albrecht,S., Bourdeau,M., Bennett,D., Mufson,E.J., Bhattacharjee,M., and LeBlanc,A.C. 2007. Activation of caspase-6 in aging and mild cognitive impairment. Am. J. Pathol. 170, 1200-1209.

Barker,N., van Es,J.H., Kuipers,J., Kujala,P., van den,B.M., Cozijnsen,M., Haegebarth,A., Korving,J., Begthel,H., Peters,P.J., and Clevers,H. 2007. Identification of stem cells in small intestine and colon by marker gene Lgr5. Nature 449, 1003-1007.

Blackburn,E.H. 1997. The telomere and telomerase: nucleic acid-protein complexes acting in a telomere homeostasis system. A review. Biochemistry (Mosc. ) 62, 1196-1201.

Boddaert,J., Mallat,Z., Fornes,P., Esposito,B., Lecomte,D., Verny,M., Tedgui,A., and Belmin,J. 2005. Age and gender effects on apoptosis in the human coronary arterial wall. Mech. Ageing Dev. 126, 678-684.

Brown,J.P., Wei,W., and Sedivy,J.M. 1997. Bypass of senescence after disruption of p21CIP1/WAF1 gene in normal diploid human fibroblasts. Science 277, 831-834.

Cenini,G., Sultana,R., Memo,M., and Butterfield,D.A. 2008. Elevated levels of pro-apoptotic p53 and its oxidative modification by the lipid peroxidation product, HNE, in brain from subjects with amnestic mild cognitive impairment and Alzheimer's disease. J. Cell Mol Med. 12, 987-994.

Chimenti,C., Kajstura,J., Torella,D., Urbanek,K., Heleniak,H., Colussi,C., Di Meglio,F., Nadal-Ginard,B., Frustaci,A., Leri,A., Maseri,A., and Anversa,P. 2003. Senescence and death of primitive cells and myocytes lead to premature cardiac aging and heart failure. Circ. Res. 93, 604-613.

Chin,L., Artandi,S.E., Shen,Q., Tam,A., Lee,S.L., Gottlieb,G.J., Greider,C.W., and DePinho,R.A. 1999. p53 deficiency rescues the adverse effects of telomere loss and cooperates with telomere dysfunction to accelerate carcinogenesis. Cell 97 , 527-538.

Choudhury,A.R., Ju,Z., Djojosubroto,M.W., Schienke,A., Lechel,A., Schaetzlein,S., Jiang,H., Stepczynska,A., Wang,C., Buer,J., Lee,H.W., Von Zglinicki,T., Ganser,A., Schirmacher,P., Nakauchi,H., and Rudolph,K.L. 2007. Cdkn1a deletion improves stem cell function and lifespan of mice with dysfunctional telomeres without accelerating cancer formation. Nat Genet. 39, 99-105.

Conboy,I.M., Conboy,M.J., Wagers,A.J., Girma,E.R., Weissman,I.L., and Rando,T.A. 2005. Rejuvenation of aged progenitor cells by exposure to a young systemic environment. Nature $433,760-764$.

d'Adda,d.F., Reaper,P.M., Clay-Farrace,L., Fiegler,H., Carr,P., Von Zglinicki,T., Saretzki,G., Carter,N.P., and Jackson,S.P. 2003. A DNA damage checkpoint response in telomere-initiated senescence. Nature 426, 194-198.

Dimri,G.P., Lee,X., Basile,G., Acosta,M., Scott,G., Roskelley,C., Medrano,E.E., Linskens,M., Rubelj,I., Pereira-Smith,O., and . 1995. A biomarker that identifies senescent human cells in culture and in aging skin in vivo. Proc. Natl. Acad. Sci. U. S. A 92, 9363-9367.

Flores I, Cayuela ML, Blasco MA. 2995.Effects of telomerase and telomere length on epidermal stem cell behavior. Science 309, 1253-6.

Gire,V., Roux,P., Wynford-Thomas,D., Brondello,J.M., and Dulic,V. 2004. DNA damage checkpoint kinase Chk2 triggers replicative senescence. EMBO J. 23, 2554-2563.

Gorenne,I., Kavurma,M., Scott,S., and Bennett,M. 2006. Vascular smooth muscle cell senescence in atherosclerosis. Cardiovasc. Res. 72, 9-17.

Guo,H., Albrecht,S., Bourdeau,M., Petzke,T., Bergeron,C., and LeBlanc,A.C. 2004. Active caspase-6 and caspase-6-cleaved tau in neuropil threads, neuritic plaques, and neurofibrillary tangles of Alzheimer's disease. Am. J. Pathol. 165, 523-531.

Harley,C.B., Futcher,A.B., and Greider,C.W. 1990. Telomeres shorten during ageing of human fibroblasts. Nature 345, 458- 
460.

Haug,K., Kravik,K.L., and De Angelis,P.M. 2008. Cellular response to irinotecan in colon cancer cell lines showing differential response to 5-fluorouracil. Anticancer Res. 28, 583-592.

Healy,A.M., Hancock,W.W., Christie,P.D., Rayburn,H.B., and Rosenberg,R.D. 1998. Intravascular coagulation activation in a murine model of thrombomodulin deficiency: effects of lesion size, age, and hypoxia on fibrin deposition. Blood 92, 41884197.

Herbig,U., Ferreira,M., Condel,L., Carey,D., and Sedivy,J.M. 2006. Cellular senescence in aging primates. Science $311,1257$.

Hjelmeland,L.M., Cristofolo,V.J., Funk,W., Rakoczy,E., and Katz,M.L. 1999. Senescence of the retinal pigment epithelium. Mol Vis. 5, 33.

Hong Y, Stambrook PJ.2004. Restoration of an absent G1 arrest and protection from apoptosis in embryonic stem cells after ionizing radiation. Proc Natl Acad Sci U S A. 101, 14443-8.

Janzen,V., Forkert,R., Fleming,H.E., Saito,Y., Waring,M.T., Dombkowski,D.M., Cheng,T., DePinho,R.A., Sharpless,N.E., and Scadden,D.T. 2006. Stem-cell ageing modified by the cyclin-dependent kinase inhibitor p16INK4a. Nature 443, $421-426$.

Jeyapalan,J.C., Ferreira,M., Sedivy,J.M., and Herbig,U. 2007. Accumulation of senescent cells in mitotic tissue of aging primates. Mech. Ageing Dev. 128, 36-44.

Jiang H., Eric Schiffer, Zhangfa Song, Jianwei Wang, Petra Zürbig, Kathrin Thedieck, Suzette Moes, Nadja Saal, Justyna Jantos, Meiken Brecht, Paul Jenö, Michael N.Hall, Klaus Hager, Micheal P Mans, Harmut Hacker, Arnold Ganser, Andrzej Bartke, Christoph Meissner, Harald Mischak, Zhenyu Ju, and K.Lenhard Rudolph. Proteins induced by telomere dysfunction and DNA damage represent biomarkers of human aging and disease. PNAS . 2008.

Ref Type: In Press

Jiang H.et al. Proteins induced by telomere dysfunction and DNA damage represent biomarkers of human aging and disease. PNAS . 2008.

Ref Type: In Press

Jiang,H., Ju,Z., and Rudolph,K.L. 2007. Telomere shortening and ageing. Z. Gerontol. Geriatr. 40, 314-324.

Ju,Z., Choudhury,A.R., and Rudolph,K.L. 2007. A dual role of p21 in stem cell aging. Ann. N. Y. Acad. Sci. 1100, $333-344$.

Ju,Z., Jiang,H., Jaworski,M., Rathinam,C., Gompf,A., Klein,C., Trumpp,A., and Rudolph,K.L. 2007. Telomere dysfunction induces environmental alterations limiting hematopoietic stem cell function and engraftment. Nat Med. 13, $742-747$.

Krishnamurthy,J., Ramsey,M.R., Ligon,K.L., Torrice,C., Koh,A., Bonner-Weir,S., and Sharpless,N.E. 2006. p16INK4a induces an age-dependent decline in islet regenerative potential. Nature 443, 453-457.

Krishnamurthy,J., Torrice,C., Ramsey,M.R., Kovalev,G.I., Al Regaiey,K., Su,L., and Sharpless,N.E. 2004. Ink4a/Arf expression is a biomarker of aging. J. Clin. Invest 114, 1299-1307.

Kujoth,G.C., Hiona,A., Pugh,T.D., Someya,S., Panzer,K., Wohlgemuth,S.E., Hofer,T., Seo,A.Y., Sullivan,R., Jobling,W.A., Morrow,J.D., Van Remmen,H., Sedivy,J.M., Yamasoba,T., Tanokura,M., Weindruch,R., Leeuwenburgh,C., and Prolla,T.A. 2005. Mitochondrial DNA mutations, oxidative stress, and apoptosis in mammalian aging. Science 309, 481-484.

Larbi,A., Kempf,J., and Pawelec,G. 2007. Oxidative stress modulation and T cell activation. Exp. Gerontol. 42, 852-858.

Lee,A.T., DeSimone,C., Cerami,A., and Bucala,R. 1994. Comparative analysis of DNA mutations in lacI transgenic mice with age. FASEB J. 8, 545-550.

Lee BY, Han JA, Im JS, Morrone A, Johung K, Goodwin EC, Kleijer WJ, DiMaio D, Hwang ES. 2006. Senescenceassociated beta-galactosidase is lysosomal beta-galactosidase. Aging Cell. 5, 187-95. 
Lieber,M.R. and Karanjawala,Z.E. 2004. Ageing, repetitive genomes and DNA damage. Nat Rev Mol Cell Biol 5, 69-75.

Maedler,K., Schumann,D.M., Schulthess,F., Oberholzer,J., Bosco,D., Berney,T., and Donath,M.Y. 2006. Aging correlates with decreased beta-cell proliferative capacity and enhanced sensitivity to apoptosis: a potential role for Fas and pancreatic duodenal homeobox-1. Diabetes 55, 2455-2462.

Marzetti,E. and Leeuwenburgh,C. 2006. Skeletal muscle apoptosis, sarcopenia and frailty at old age. Exp. Gerontol. 41, 1234-1238.

Maser,R.S., Choudhury,B., Campbell,P.J., Feng,B., Wong,K.K., Protopopov,A., O'Neil,J., Gutierrez,A., Ivanova,E., Perna,I., Lin,E., Mani,V., Jiang,S., McNamara,K., Zaghlul,S., Edkins,S., Stevens,C., Brennan,C., Martin,E.S., Wiedemeyer,R., Kabbarah,O., Nogueira,C., Histen,G., Aster,J., Mansour,M., Duke,V., Foroni,L., Fielding,A.K., Goldstone,A.H., Rowe,J.M., Wang,Y.A., Look,A.T., Stratton,M.R., Chin,L., Futreal,P.A., and DePinho,R.A. 2007. Chromosomally unstable mouse tumours have genomic alterations similar to diverse human cancers. Nature 447, 966-971.

Melk,A., Schmidt,B.M., Takeuchi,O., Sawitzki,B., Rayner,D.C., and Halloran,P.F. 2004. Expression of p16INK4a and other cell cycle regulator and senescence associated genes in aging human kidney. Kidney Int. 65, 510-520.

Mimura,T. and Joyce,N.C. 2006. Replication competence and senescence in central and peripheral human corneal endothelium. Invest Ophthalmol. Vis. Sci. 47, 1387-1396.

Minamino,T., Miyauchi,H., Yoshida,T., Ishida,Y., Yoshida,H., and Komuro,I. 2002. Endothelial cell senescence in human atherosclerosis: role of telomere in endothelial dysfunction. Circulation 105, 1541-1544.

Molofsky,A.V., Slutsky,S.G., Joseph,N.M., He,S., Pardal,R., Krishnamurthy,J., Sharpless,N.E., and Morrison,S.J. 2006. Increasing p16INK4a expression decreases forebrain progenitors and neurogenesis during ageing. Nature 443, 448-452.

Mullaart,E., Boerrigter,M.E., Ravid,R., Swaab,D.F., and Vijg,J. 1990. Increased levels of DNA breaks in cerebral cortex of Alzheimer's disease patients. Neurobiol. Aging 11, 169-173.

Nijnik,A., Woodbine,L., Marchetti,C., Dawson,S., Lambe,T., Liu,C., Rodrigues,N.P., Crockford,T.L., Cabuy,E., Vindigni,A., Enver,T., Bell,J.I., Slijepcevic,P., Goodnow,C.C., Jeggo,P.A., and Cornall,R.J. 2007. DNA repair is limiting for haematopoietic stem cells during ageing. Nature 447, 686-690.

Panda,S., Isbatan,A., and Adami,G.R. 2008. Modification of the ATM/ATR directed DNA damage response state with aging and long after hepatocyte senescence induction in vivo. Mech. Ageing Dev. 129, 332-340.

Parrinello,S., Samper,E., Krtolica,A., Goldstein,J., Melov,S., and Campisi,J. 2003. Oxygen sensitivity severely limits the replicative lifespan of murine fibroblasts. Nat Cell Biol 5, 741-747.

Rando,T.A. 2007. The immortal strand hypothesis: segregation and reconstruction. Cell 129, 1239-1243.

Rass,U., Ahel,I., and West,S.C. 2007. Defective DNA repair and neurodegenerative disease. Cell 130, 991-1004.

Rossi DJ, Bryder D, Seita J, Nussenzweig A, Hoeijmakers J, Weissman IL. 2007. Deficiencies in DNA damage repair limit the function of haematopoietic stem cells with age. Nature 447, 725-9.

Rossi DJ, Seita J, Czechowicz A, Bhattacharya D, Bryder D, Weissman IL. 2007b.Hematopoietic stem cell quiescence attenuates DNA damage response and permits DNA damage accumulation during aging.

Cell Cycle. 6, 2371-6.

Rossi,D.J., Jamieson,C.H., and Weissman,I.L. 2008. Stems cells and the pathways to aging and cancer. Cell 132, 681-696.

Sabatier,L., Ricoul,M., Pottier,G., and Murnane,J.P. 2005. The loss of a single telomere can result in instability of multiple chromosomes in a human tumor cell line. Mol Cancer Res. 3, 139-150.

Satyanarayana,A., Greenberg,R.A., Schaetzlein,S., Buer,J., Masutomi,K., Hahn,W.C., Zimmermann,S., Martens,U., Manns,M.P., and Rudolph,K.L. 2004. Mitogen stimulation cooperates with telomere shortening to activate DNA damage responses and senescence signaling. Mol Cell Biol 24, 5459-5474.

Schaetzlein,S., Kodandaramireddy,N.R., Ju,Z., Lechel,A., Stepczynska,A., Lilli,D.R., Clark,A.B., Rudolph,C., Kuhnel,F., 
Wei,K., Schlegelberger,B., Schirmacher,P., Kunkel,T.A., Greenberg,R.A., Edelmann,W., and Rudolph,K.L. 2007. Exonuclease-1 deletion impairs DNA damage signaling and prolongs lifespan of telomere-dysfunctional mice. Cell 130, 863877.

Sedelnikova,O.A., Horikawa,I., Zimonjic,D.B., Popescu,N.C., Bonner,W.M., and Barrett,J.C. 2004. Senescing human cells and ageing mice accumulate DNA lesions with unrepairable double-strand breaks. Nat Cell Biol 6, 168-170.

Serrano,M., Lin,A.W., McCurrach,M.E., Beach,D., and Lowe,S.W. 1997. Oncogenic ras provokes premature cell senescence associated with accumulation of p53 and p16INK4a. Cell 88, 593-602.

Sherr,C.J. and DePinho,R.A. 2000. Cellular senescence: mitotic clock or culture shock? Cell 102, 407-410.

Song, Z. Ju, Z and Rudolph, K. L.Cell inteinsic and extrinsic mechanisms of stem cell aging depend on telomere status. Exp.Gerontol. Article in press. 2008.

Ref Type: In Press

Stein,G.H., Drullinger,L.F., Soulard,A., and Dulic,V. 1999. Differential roles for cyclin-dependent kinase inhibitors p21 and p16 in the mechanisms of senescence and differentiation in human fibroblasts. Mol Cell Biol 19, 2109-2117.

Suzuki,M. and Boothman,D.A. 2008. Stress-induced premature senescence (SIPS)--influence of SIPS on radiotherapy. J. Radiat. Res. (Tokyo) 49, 105-112.

Tarnawski,A., Pai,R., Deng,X., Ahluwalia,A., Khomenko,T., Tanigawa,T., Akahoshi,T., Sandor,Z., and Szabo,S. 2007. Aging gastropathy-novel mechanisms: hypoxia, up-regulation of multifunctional phosphatase PTEN, and proapoptotic factors. Gastroenterology 133, 1938-1947.

Vijg,J. 2008. The role of DNA damage and repair in aging: New approaches to an old problem. Mech. Ageing Dev. 129, 498502.

Wiemann,S.U., Satyanarayana,A., Tsahuridu,M., Tillmann,H.L., Zender,L., Klempnauer,J., Flemming,P., Franco,S., Blasco,M.A., Manns,M.P., and Rudolph,K.L. 2002. Hepatocyte telomere shortening and senescence are general markers of human liver cirrhosis. FASEB J. 16, 935-942.

Wiktor-Brown DM, Olipitz W, Hendricks CA, Rugo RE, Engelward BP. 2008. Tissue-specific differences in the accumulation of sequence rearrangements with age. DNA Repair (Amst). 7, 694-703.

Wright,W.E. and Shay,J.W. 1992. The two-stage mechanism controlling cellular senescence and immortalization. Exp. Gerontol. 27, 383-389.

Xue,W., Zender,L., Miething,C., Dickins,R.A., Hernando,E., Krizhanovsky,V., Cordon-Cardo,C., and Lowe,S.W. 2007. Senescence and tumour clearance is triggered by p53 restoration in murine liver carcinomas. Nature 445, 656-660.

Ye,X., Zerlanko,B., Kennedy,A., Banumathy,G., Zhang,R., and Adams,P.D. 2007. Downregulation of Wnt signaling is a trigger for formation of facultative heterochromatin and onset of cell senescence in primary human cells. Mol Cell 27, 183196.

Zou,Y., Sfeir,A., Gryaznov,S.M., Shay,J.W., and Wright,W.E. 2004. Does a sentinel or a subset of short telomeres determine replicative senescence? Mol Biol Cell 15, 3709-3718. 
Table 1. Evidence for an accumulation of nuclear DNA damage during aging

\begin{tabular}{|c|c|c|}
\hline \begin{tabular}{|l|}
$\begin{array}{l}\text { Marker of DNA } \\
\text { damage }\end{array}$ \\
\end{tabular} & spec & Affected organ \\
\hline $\begin{array}{l}\text { DNA damage - } \\
\text { foci, e.g. } \gamma \mathrm{H} 2 \mathrm{AX}\end{array}$ & $\begin{array}{l}\text { human } \\
\text { primate } \\
\text { mouse }\end{array}$ & $\begin{array}{l}\text { Increase in lymphocytes (Sedelnikova et al., 2008) } \\
\text { Increase in ulcerative colitis (Risques et al., 2008) } \\
\text { Increase in skin but not muscle (Herbig et al., 2006, Jeyapalan et al., } \\
2007 \text { ) } \\
\text { Increase in liver, testis, kidney, lung, brain (Sedelnikova et al., 2004) } \\
\text { Increase in liver (Panda et al., 2008) }\end{array}$ \\
\hline $\begin{array}{|lr|}\text { Fragmented } & \text { DNA } \\
\text { (double } & \text { strand } \\
\text { breaks) } & \\
\end{array}$ & $\begin{array}{l}\text { Human } \\
\text { rat } \\
\text { mouse }\end{array}$ & $\begin{array}{l}\text { Increase in brain of patients with Alzheimer or cognitive impairment } \\
\text { (Mullaart et al., 1990) } \\
\text { Increase in sperm (Schmid et al., 2007, Singh et al., 2003) } \\
\text { Increase in muscle (Sundaram et al., 2006), liver (Higami et al., 1994) } \\
\text { Increase in kidney (Singh et al. 2001) }\end{array}$ \\
\hline $\begin{array}{l}\text { fluorometric } \\
\text { analysis of DNA } \\
\text { unwinding (single } \\
\text { strand breaks) }\end{array}$ & $\begin{array}{l}\text { rat } \\
\text { mouse }\end{array}$ & $\begin{array}{l}\text { No significant increase in peripheral blood lymphocytes (Singh et al., } \\
\text { 1991) } \\
\text { Increase in peripheral blood lymphocytes (Chicca et al. 1996) } \\
\text { Increase in liver but not in brain (Mullaart et al., 1990) } \\
\text { No increase in brain, liver, and kidney (Fu et al., 1991) }\end{array}$ \\
\hline $\begin{array}{l}\text { Homologous } \\
\text { recombination } \\
\text { reporter mouse }\end{array}$ & mouse & $\begin{array}{l}\text { Increase rates of homologous recombination in pancreas but not in skin } \\
\text { (Witkor-Brown et al., 2008) }\end{array}$ \\
\hline $\begin{array}{|lr|}\text { DNA } & \text { damage } \\
\text { signalling } & (\text { p53, } \\
\text { p21, p16) } & \end{array}$ & $\begin{array}{l}\text { rat } \\
\text { mouse }\end{array}$ & $\begin{array}{l}\text { Increase in brain of patients with Alzheimer or cognitive impairment } \\
\text { (Cenini et al., 2008) } \\
\text { Increase in bone marrow derived stroma cells (Zhou et al., 2008) } \\
\text { Increase in kidney (Melk et al., 2004) } \\
\text { Increase in skeletal muscle (Welle et al., 2004) } \\
\text { Increase in skeletal muscle (Tamilselvan et al., 2007) } \\
\text { Increase in kidney (Ding et al., 2001, Melk et al., 2003) } \\
\text { Increase in skeletal muscle (Edwards et al., 2007) }\end{array}$ \\
\hline
\end{tabular}




\section{ACCEPTED MANUSCRIPT}

Table 2. Evidence for an accumulation of senescent cells in aged tissues

\begin{tabular}{|c|c|c|}
\hline $\begin{array}{ll}\begin{array}{l}\text { Marker } \\
\text { senescence }\end{array} & \text { of }\end{array}$ & species & Affected organ \\
\hline $\begin{array}{l}\text { DNA damage foci } \\
\text { at telomere (TIFs) }\end{array}$ & baboons & $\begin{array}{l}\text { Increase in skin but not in muscle (Herbig et al. 2006, Jeyapalan et al. } \\
\text { 2007) }\end{array}$ \\
\hline SA- $\beta$-Gal & $\begin{array}{l}\text { human } \\
\\
\\
\text { rhesus } \\
\text { monkey } \\
\text { rat }\end{array}$ & $\begin{array}{l}\text { Increase in skin (Dimri et al., 1995) } \\
\text { No increase in skin (Severino et al. 2000) } \\
\text { Increase in cornea (Mimura and Joyce, 2006) } \\
\text { Increase in ischemic heart (Minamino et al., 2002) } \\
\text { Increase in endarterectomy plaque (Gorenne et al., 2006) } \\
\text { No increase in gastrointestinal epithelium (Going et al., 2002) } \\
\text { Increase in articular chondrocytes (Martin and Buckwalter, 2001) } \\
\text { Increase in chronic hepatitits and cirrhosis (Paradis et al., 2001, } \\
\text { Wiemann et al., 2002) } \\
\text { Increase in retina (Hjelmeland et al., 1999) } \\
\text { Increase in kidney (Melk et al., 2004, Ding et al., 2001) }\end{array}$ \\
\hline \multicolumn{2}{|c|}{$\begin{array}{l}\text { DNA damage signaling } \\
\text { associated with senescence (p53, } \\
\text { p21, p16) }\end{array}$} & see Table 1 \\
\hline
\end{tabular}




\section{ACCEPTED MANUSCRIPT}

Table 3. Evidence for an increase in apoptosis in aged tissues

\begin{tabular}{|c|c|c|}
\hline $\begin{array}{l}\text { Marker } \\
\text { apoptosis }\end{array}$ & species & affected organ \\
\hline $\begin{array}{l}\text { Pro-apoptosis } \\
\text { signaling: } \\
\text { Fas, } \\
\text { cytochrome } \\
\text { bax, caspases }\end{array}$ & $\begin{array}{l}\text { human } \\
\text { rat } \\
\text { mouse }\end{array}$ & $\begin{array}{l}\text { Increase in peripheral blood T-lymphocytes (Aggarwal and Gupta, 1998) } \\
\text { Increase in brain (Guo et al., 2004) } \\
\text { Increase in lung (Healy et al., 1998) } \\
\text { Increase in pancreas (Maedler et al., 2006) } \\
\text { Increase in Alzheimer's disease (Rohn et al., 2001) } \\
\text { Increase in skeletal muscle (Tamilselvan et al., 2007) } \\
\text { Increase in heart (Phaneuf and Leeuwenburgh, 2002) } \\
\text { Increase in liver (Ando et al. 2002) } \\
\text { Increase in skeletal muscle, testis, liver, and heart (Kujoth et al., 2005) } \\
\text { Thymus involution is Fas-dependent (Yajima et al., 2004) }\end{array}$ \\
\hline $\begin{array}{l}\text { Anti-apoptosis } \\
\text { Signaling: } \mathrm{Bcl} 2 \text {, } \\
\text { Bcl-xl }\end{array}$ & human & $\begin{array}{l}\text { Decrease in peripheral blood T-lymphocytes (Aggarwal and Gupta, } \\
\text { 1998) } \\
\text { Decrease in heart (Phaneuf and Leeuwenburgh, 2002) }\end{array}$ \\
\hline $\begin{array}{l}\text { DNA } \\
\text { fragmentation }\end{array}$ & $\begin{array}{l}\text { human } \\
\text { rat } \\
\text { mouse }\end{array}$ & $\begin{array}{l}\text { Increase in Alzheimer's disease (Su et al. 1994) } \\
\text { Decrease in sperm (Singh et al., 2003) } \\
\text { Increase in chondrocytes of articular knee (Adams and Horton, 1998) } \\
\text { Increase in chondrocytes of articular knee (Adams and Horton, 1998) }\end{array}$ \\
\hline
\end{tabular}

